\title{
Business Process Reengineering and Organizational Performance: A Study of Innoson Technical and Industrial Company, Emene, Enugu, Nigeria
}

\author{
Nwekpa Kenneth C, Ngwuta Christopher I, Elom Mathias E
}

\begin{abstract}
This study, Business Process Reengineering and Organizational Performance, spawns from the need to explore the relationship between business process reengineering and organizational performance of Innoson Technical and Industrial Company, Emene, Enugu. The main objectives are: to ascertain the degree to which each of the three decomposed variables of business process reengineering of creative rethinking, radical change and fundamental thinking relate to profitability, market share and business sustainability dimensions of performance of Innoson Technical and Industrial Company, Emene, Enugu. The study was a survey type of research of which correlational research design was employed to ascertain the degree of the magnitude of the relationship between the studied variables. Structured questionnaire was administered on the sample of two hundred and sixty one (261), out of which, two hundred and fifty (250) copies of questionnaire were successfully returned, hence used for the analysis. Data collected from the respondents were analyzed with Pearson Correlation Coefficient. The study found a significant relationship between creative rethinking and profitability of Innoson Company $(r=0.60)$, a significant relationship between radical change and market share of Innoson Company $(r=0.91)$, and significant relationship between fundamental thinking and business sustainability of Innoson Company of Innoson Company $(r=0.62)$. The implication of the findings is that effective implementation of business process reengineering thrive high performing organizations in meeting the demands of changing business environment. From the findings, the study concludes that organizations could enhance their performance, if business process reengineering is conducted effectively and recommended that the management of Innoson Technical and Industrial Company should pay adequate attention to issues relating to business process reengineering, taking into cognizance its pertinent role in radical improvement on cutting down operational costs, cycle time reduction, quality enhancement and service improvement that predict organizational performance.
\end{abstract}

Keywords: Business process re-engineering, organizational performance, operational cost, cycle time reduction, quality enhancement and service improvement.

\section{Introduction}

Organizations operate in dynamic environments that are highly characterized by unpredictable economic climate orchestrated by continual advancements in science and technology. Due to the global changes in economy, markets are globalized, customer requirements changed and competition is intensified, and new approaches in business operations were to be developed for coping with environmental dynamics and this facilitated the organization's predisposed desire for change (Martins, 2012). Business processes are changing, organizations exert considerable efforts to re-evaluate and reengineer processes in an attempt to meet the demands of the changing business environment (Jain and Aggarwal, 2011). Huge (2000) posits that organizations should not ignore the place of business re-engineering giving the dynamism of business environment in their day-to-day planning, in terms of resource allocation, mobilization, and utilization for improved performance. Therefore, meeting the demands of changing business environment made organizations especially Innoson Technical and Industrial Company to align its operations by co-opting business process reengineering to sustain and improve their competitiveness. Therefore, business process reengineering is a fundamental re-thinking and re-structuring of business processes to achieve a sustainable improvement on operations management for the desired performance (Huge, 2000).

The concept of reengineering traces its roots back to management theories developed in the early 19th century. It started as a private sector technique designed to assist organizations fundamentally rethink how best to perform their work in order to enhance customer service, reduce operational costs, and improve their competitiveness (Huge, 2000). BPR as observed by Beck (2014) seeks to help organizations radically restructure their operations by focusing on the ground-up design necessary for business process. BPR evolves on three divergent spheres of changes to include process improvement, evolutionary BPR, and revolutionary BPR (Jain and Aggarwal, 2011). It involves identifying presently how business process operate, how to restructure these processes in an attempt to get rid of wasted effort to improve efficiency, and how to effectively implement the process changes for business sustainability in the changing environment. 
Jain and Aggarwal (2011) contend that business process reengineering is a fundamental rethinking and radical redesign of the business process to achieve dramatic improvement in critical contemporary measures of cost reduction, quality enhancement, service improvement and circle time reduction. Huge (2000) posits that Information Technology plays a major role in business process reengineering as it provides office automation, it allows the business to be conducted in different locations, provides flexibility in manufacturing, permits quicker delivery to customers and supports rapid and paperless transactions. In general, it allows an efficient and effective change in the manner in which work is performed. Business Process Reengineering according to Nickson (2001) involves devising new methods of organizing tasks, effective coordination of individual workers in the light of their tasks, and redesigning the system to achieve and sustain greater operational effectiveness and efficiency that will afford them greater leverage for organizational performance. As a result, organizations are increasingly demanding for superior skills, especially on operations management that have operational capability to re-evaluate and reengineer business processes driven in-between time giving the dynamism of business environment.

Innoson Technical and Industrial Company is a subsidiary of Innoson group of companies which was incorporated in 2002. The company starts its full scale production in October, 2002. Innoson Company specializes in the production of house hold products to include plastic chairs, trays, spoons, jerry cans, and different types of plastic plates. The company's production injection moulds has the production capacity, which accounts for three (3) production runs per day (Innoson Bulletin, 201 5).

\subsection{Statement of the Problem}

The basic tenet of organizational performance is the ability of managers to re-evaluate and re-engineer their business processes given the dynamism of business environment. Business process reengineering plays a pivotal role in redesigning the business processes which is considered most appropriate in achieving radical improvement in the areas of service improvement, quality enhancement, and cost reduction that afford organizations greater leverage to improve their competitiveness (Hammer, 2014). Therefore, it deserves to be handled as a major policy variable necessary for efficient allocation of resources in meeting the demands of the environment. The study observed that operations managers responsible for reengineering processes in Innoson Company have little business reengineering process operational skills and has resulted in misapplication of it. This situation tends to undermine the conceptualization of creative ideas and fundamental thinking necessary for dramatic improvement in operations management. The apparent difficult in conceptualizing creative ideas may have undermined the realization of business process reengineering goal of cutting down operational costs in their production runs, as a result incur cost in their production runs and may have affected the organizational profitability of Innoson Company. But, the extent it affect the organizational profitability is yet to be established, hence this study.

Research findings according to Hammer (2014) have linked misapplication of business process reengineering to negative outcomes for individual workers, and organizational performance. These outcomes according to Jain and Aggarwal (2011) include low performance, poor process improvement, increased tardiness, re-activeness, dearth of radical change, and low commitment to work. The possibility of issues relating to dearth of radical change may be contributing to problems of low quality and service improvement in Innoson Technical and Industrial Company and may have affected their market share. Therefore, it would be difficult to determine the underlying net effect(s) of the degree of interactions and its relationship between creative rethinking on profitability, radical change on market share, and fundamental rethinking on business sustainability of Innoson Technical and Industrial Company, without research-based evidence, hence this study.

\subsection{Objectives of the Study}

The general objective of the study is to determine the effect of business process reengineering on organizational performance. Specifically, the objectives are:

1 To determine the extent to which creative rethinking relates to profitability of Innoson Technical and Industrial Company, Emene, Enugu.

2 To ascertain the extent to which radical change relates to market share of Innoson Technical and Industrial Company, Emene, Enugu.

3 To examine the extent to which fundamental rethinking relates to business sustainability of Innoson Technical and Industrial Company, Emene, Enugu.

\subsection{Research Hypotheses}

$\mathrm{H}_{01}$ : Creative rethinking does not significantly relates to profitability of Innoson Technical and Industrial Company, Emene, Enugu

$\mathrm{H}_{02}$ : Radical change does not significantly relate to market share of Innoson Technical and Industrial Company, Emene, Enugu.

$\mathrm{H}_{03}$ : Fundamental thinking does not significantly relates to business sustainability of Innoson Technical and Industrial Company, Emene, Enugu 


\subsubsection{Concept of Business Process Reengineering}

\section{Review Of Related Literature}

John (2000) posits that business process reengineering is concerned with the fundamental rethinking and radical design of core business processes in an attempt to achieve tremendous improvement especially on three critical measures to include cost, quality, time, speed, and service. Business process reengineering according to John (2000) evolves changes in all existing business structures and processes that will allow organizations to be more effective in meeting the demands of the changing environment. The effective implementation of business process reengineering is the relative strength of individual's operational dexterity in redesigning the workflow processes in organization (Bruce, 2010).

Stephen (2015) posits that business process reengineering involve total transformation of business, its existing structures, technologies and value systems in an attempt to achieve and maintain greater operational effectiveness and efficiency for improved competitiveness. Bruce (2010) observed that since the environment of business operations are consistently in the state of flux, it become imperative that organizations should have operations managers with the desired operational capability to re-engineer their business processes that will afford the organizations greater leverage for enhanced organizational performance. Hammer (2014) contends that re-engineering business processes does not only enhance incremental improvement, but crave for quantum leaps in performance. Such performance according to Hammer (2014) includes reduced cost, increased speed, greater accuracy, improved services, and quality of work.

Guru (2013) sees business process reengineering as the examination and adjustment of existing strategy, process, organization, beliefs, and their value system. This, however, involves a thorough evaluation of the organizational structure, since choice of strategy is relatively associated to environmental characteristics. John (2000) posits that organizational performance results not only from the match between environmental and strategy, but also from the use of an appropriate organization structure. Freeman (2014) argues that business process reengineering evolve around instituting and defining customer requirements and then align the entire reengineer processes, cutting across all the departments, for a sustainable framework that would allow the organization to be more effective in redesigning the entire process. Redesigning the entire process as observed by Freeman (2014) has the potential to eliminate all wasted effort in the organization thereby creating enabling environment for continuous improvement through employees' commitment to work.

Hammer (2014) affirms that business process reengineering is concerned with consistent thinking and the relinquishing of outdated methods, rules, structures and assumptions that underlie operations management in organizations. The seeming drive of business re-engineering is to ensure quality, service improvement and cost reductions as a prerequisite condition for meeting the demands of the changing environment (Goetsch and Davis, 2000). Fundamentally, BPR is a move away from linear and sequential thinking to a holistic, all-ornothing, and redesigning the entire processes that allow for rapid and dramatic improvements in operations. Sengupta, Bhattachrya and Sengupta (2012) identified the following as general steps of effective BPR.

i) Identify the objectives and define the scope of business process reengineering: This will helps the organization to streamline their actions in the light of the objective she intends to achieve. The implementation of business process reengineering according to Miller (2000) must align with the objectives of the organization. Miller (2000) also contends that the efficacy of BPR drives especially when operation managers have understanding and appreciate the prevailing variables of the environment.

ii) Gather necessary information to be used in designing the new process which may flow from employees, customers, and competitors: The organization must assess the market in order to monitor their products. This, however, will enable the organization to have detailed information about customer requirement on company's products. Miller (2000) observed that obtaining such pertinent information underscores organizations" efforts in implementing effective business process reengineering.

iii) Create and implement an action plan: Creating a convivial atmosphere for effective implementation of BPR drives when relevant information regarding company's products is obtained with respect to customers' perception, attrition signals and customers' requirement needed for smooth implementation of reengineering processes. The foregoing is absolutely imperative, considering the fact that business process reengineering needs should have a considerable impact on every segments of the organization to yield the desired results.

Furthermore, Willy (2014) writes that reengineering is about serving the external environment through improved customer service, and not simply about meeting a narrow range of internal performance targets. Therefore, reengineering according to Willy (2014) is radically new process of organizational change that seeks to align operation management in line with the prevailing provisions of the environment. The reality and relevance of redesigning the entire processes underpinned the firm's efforts to buoy up organizational performance through the instrumentality of business process reengineering (Sengupta, Bhattacharya and Sengupta, 2012). The above assertion is consistent with the presupposition of Docky (2000) who said that the resultant effect of effective business process reengineering results to improve performance. 
More so, Arora (2010) opined that BPR brings out both identified and un-identified deficiencies of the existing system and attempts to optimize productivity through restructuring and redesigning the processes towards superior performance. Business process reengineering as identified by Docky (2000) is consciously employed by most manufacturing firms as half-hearted attempt at catalyzing change that seeks to address issues relating to attrition. The change is aimed at engendering goal-directed behavior enshrined in the management cathedral as described as most powerful and possibly most maligned management indispensable tool. It is therefore, the most sharply focused practice that has delivered extraordinary benefits especially to those firms who have adhered to the following fundamentals: It must be process-centric, redesign-ruled, radical and dramatic. These fundamentals are essentially vital in achieving radical improvement due to the fact that they use various techniques combined with enabling technologies in providing explosive mix to make dramatic changes throughout the organization and deliver what the customer request through customer relationship management (Klein, 2000). The foregoing suggests that business process reengineering utilizes and blend various components into a synergistic whole. In the light of the above definitions, the study sees business process reengineering as a holistic and systematic approach of evaluating the existing method of operations in organization with a view to developing of more effective ways of doing business in order to make the operation management faster, more cost effective, and qualitative.

\subsubsection{Dimensions of Business Process Re-engineering}

Hammer (2014) outlined the following four dimensions of business process reengineering to include creative rethinking, process function, radical change, and fundamental rethinking.

\section{Creative Rethinking}

Creative rethinking is a process of conceptualizing a constructive idea that is novel, new and potentially useful. Creative thinking allows the organization to take advantage of opportunities which emanate from the changing environment (Tosin, 2000). Creative thinking is the act of turning new and imaginative ideas into reality. It is characterized by the ability to perceive the world in new ways, to find hidden patterns, to make connections between seemingly unrelated phenomena, and to generate solutions (John, 2000).

\section{Process Function}

Process function is concerned with the assemblage of tasks that relatively create value for customer (Veer, 2000). Process function according to Champy (1993) makes reengineering process fragmented across many departments in organization. For instance, order fulfillment is a process, which cut across many organizational units such as sales, accounting, production, and delivery of value of customers by the operations managers.

\section{Radical Change}

Radical change consists of wiping out the formal structures and pattern of operations in order to come up with a process in entirely new pattern that permits dramatic improvement on quality and efficient service delivery in the organization (Veer, 2000). Since the environment of business operations is in a state of flux, Hickson (2009) opined that operations managers should take abreast of its environment and proactively respond to it for business sustainability. On the other hand, radical design of strategic value added business processes and the system's policies and organization structure that support them to optimize the workflows and productivity in organization.

\section{Fundamental Rethink}

This suggests that operations managers must ask some basic questions about the organizations on their mode of operations, their vision, mission statement, value system, and organizational norms to guide them in making pertinent decision on re-engineering processes (Hickson, 2009). Fundamental rethinking of operating processes and organization structure focused on the organizations core competencies to achieve dramatic improvement in organizational performance. Fundamental rethinking must consists the 6R's.

Figure 1: Fundamental Rethinking Process

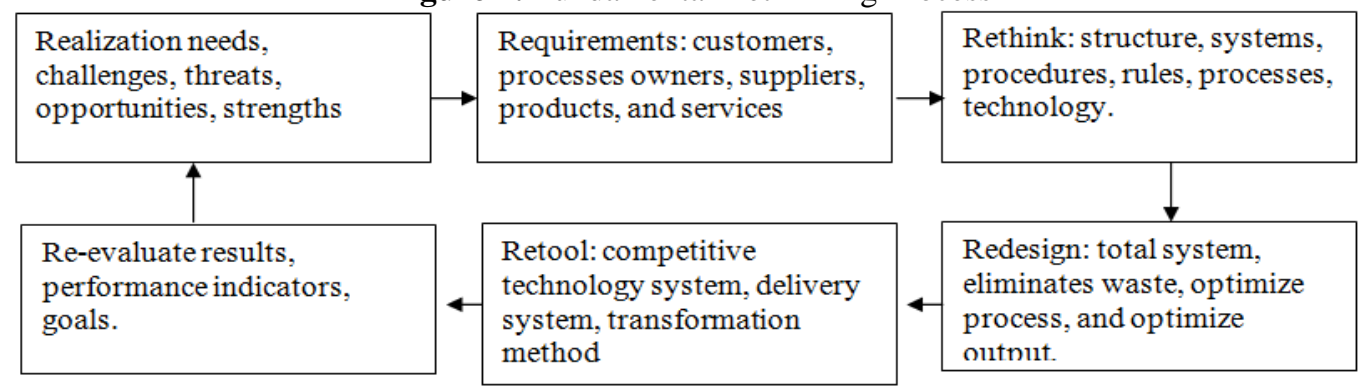

Source: Arora (2010:497). 
Figure 1 above shows the sequence of fundamental rethinking processes that must be evaluated in reengineering process in typical organization. It revealed that organization must examine its operational capability to identify its challenges, threats, opportunity, and strength (SWOT). The identification of their challenges and threats would help the organization to channel their actions appropriately. This involves assessing the market, taking account of customer complaints on the products, re-examination of the supply chain, and check attrition signals. The above requirements will help the organization to rethink especially on how to re-shape the structure, the entire systems, method of operations, rules, processes and the technology in use. The aftermath of rethinking, is to re-evaluate the desired results with performance indicators such as: quality of work, market share, profitability, business sustainability etc. Conversely, retooling is concerned with total change of the entire system, technology, and delivery system to dove-tail appropriately with the changing environment. Finally, every waste is eliminated as re-design is ensured which result to optimization of output in organization.

\subsubsection{Organizational Reengineering}

Organizational reengineering is primarily rooted upon two interacting factors as identified by Arora (2010). Total customer satisfaction and Effective and efficient internal process. Change processes, such as total quality management, which perhaps focused on quality improvement that leads to customer satisfaction. It requires constant monitoring and consistent market assessment about product quality, in line with customers' expectation. These changes, however, usually take place within the current corporate structure of the organization.Organizational and business process reengineering as observed by Klotter, (2012) are the structured processes used to design those radical changes in an attempt to meet the demands of the changing environment. Therefore, organizational reengineering according to Arora (2010), is a process by which organizations become world-class competitors by remaking their information systems, their organizations, their ways of working together, and the means by which they interact with each other and their customers. Arora (2010) identified the following four major components of organizational reengineering. They are:

i) A greater concentration on the organization's customers.

ii) A fundamental rethinking of the entire processes in the organization that perhaps result to improvement in productivity and cycle time.

iii) A structured reorganization, typically breaking functional hierarchies into cross-functional teams.

iv) New information and measurement systems, using the latest technology to drive improved data distribution and decision making.

The four components of reengineering stated above captured the fundamental rethinking processes that seeks to redesign organizational structure, with emphasis on organization's core competencies entrenched to achieve dramatic improvement in organizational performance (Moruah, 2012).

\subsubsection{Organizational performance and its Measures}

The following are the performance variables and its measures.

\section{i) Profitability}

Nick and Flick (2000) posit that profitability is the ability of business organization to earn a profit. A profit is a return on investment and it is measured by price to earning ratio. It is what is left of the total revenue after paying all the expenses associated to it. David (2003) accentuates that profitability is measured with income and expenses. Profitability and business sustainability are intricately related because every business organization strives to make profit to remain in business.

\section{ii) Market share}

Market share according to Adeyemi (2000) is the proportion of the total market controlled by organization's products. It is the volume of patronage organizational products enjoyed relative to other products in the same industry. Adeyemi (2000) contends that high market share justifies high performing organizations; therefore, it is a measure of organizational performance.

\section{iii) Business sustainability}

Research findings have linked business sustainability as strong construct for organizational performance (Noah, 2001). Business sustainability according to Chukwu (2004) is keeping the firm a going concern. It is conspicuous that every business organization that has existed overtime has done so, simply because of its operational dexterity in efficient service delivery to its customers. 


\section{Theoretical Framework}

The underpinning theory of this study is Business Action Theory which was propounded by Goldkuhl (1996). The theory assumes that the changing environment of business operations predisposed organizations to take certain business actions in re-evaluating their performance in the light of the stated objective of the organization. This, however, is premised on the ground that the dynamism of business environment is orchestrated by the interplay among various elements of the environment, and as such, organizations must exert considerable efforts to improve their performance by strategically redesigning their business processes in meeting the demands of the environment.

Goldkuhl (1996) identified six critical but largely divergent phases that predisposed organizations to take business actions. There are: business establishment phase, exposure to business environment phases, contact establishment phase, contractual phase, fulfillment phase, and completion phase. These phases according to Goldkuhl (1996) described various business actions that enable organizations to interact with its environment especially when re-evaluating the business processes. The assumptions of the theory are as follows:

i) Improved organizational performance is essentially enhanced when operations managers proactively respond to its changing environment.

ii) The ability of organization to re-evaluate their business processes sustain and improve their competitiveness.

iii) Organization takes certain business actions in redesigning their business processes in an attempt to meet the demands of the environment.

The theory overtly relates to the present study as it laid emphases on the need for organizations to take abreast of its changing environment in order to effectively re-design its business process for improved competitiveness. The aforementioned presupposes that organizational performance largely depends on the way operations managers re-evaluate and re-engineer their business processes giving the dynamism of business environment.

\section{Methodology}

The study was a survey-type of research that employed a correlational research design in an attempt to identify the direction and the magnitude of the relationship between variables under study. Structured questionnaire drawn on 5 point scale rating was administered to a sample of two hundred and sixty-one (261) respondents drawn from the population of the study. The test re-test approach was employed such that cronbach alpha coefficient was used to determine the reliability of the research instrument. Therefore, the reliability test yielded Cronbachi's alpha of $0.86,0.85$ and 0.78 for creative thinking on profitability, radical change on market share and fundamental thinking on business sustainability, suggesting that the data instrument was reliable. The data collected were presented in tables and simple percentage to determine the frequency of their responses. Product moment correlation coefficient ( $r$ ) was used to establish the degree of the relationship between the studied variables and $\mathrm{t}$ - test was also used to test the significance of the result of research hypotheses. Below is the formular:

$$
\begin{array}{ll}
\mathrm{r}= & \frac{\mathrm{n} \sum \mathrm{XY}-\left(\sum \mathrm{X}\right)\left(\sum \mathrm{Y}\right)}{\left(\mathrm{n} \Sigma \mathrm{X}^{2}-(\Sigma \mathrm{X})^{2}\left(\mathrm{n} \Sigma \mathrm{Y}^{2}-(\Sigma \mathrm{Y})^{2}\right.\right.} \\
\text { where } & \begin{array}{l}
\mathrm{r}=\text { Correlation coefficient to be determined } \\
\sum
\end{array} \\
& \begin{array}{l}
\mathrm{X}=\text { Summation } \\
\mathrm{Y}=\text { Independent variable in the paired observation } \\
\mathrm{n}=\text { Number of paired observations }
\end{array}
\end{array}
$$

Where the t-statistic is expressed as:

$t_{c}$

$$
\frac{r \sqrt{n-2}}{\sqrt{1-r^{2}}}
$$

Where tc $=$ Unknown test of significance

$$
\begin{aligned}
& \mathrm{N}=\text { Number of observations } \\
& \mathrm{r}^{2}=\text { Coefficient of determination } \\
& 1=\text { Constant } \\
& \mathrm{n}-2=\text { Degree of freedom }
\end{aligned}
$$


Data generated were presented in frequency tables, percentages and hypotheses formulated were respectively tested such that Pearson correlation coefficient formed the bases upon which the direction and magnitude of the relationship of the studied variables were established.

\section{Results}

Table 1: Questionnaire Response Rate

\begin{tabular}{|lcc|}
\hline Questionnaire & Number & Percentage \% \\
\hline Questionnaire administered & 261 & 100 \\
Questionnaire collected & 250 & 96 \\
Questionnaire not collected & 11 & 4 \\
Questionnaire used for analysis & 250 & 96 \\
\hline
\end{tabular}

Source: Field survey, (2016)

Table above shows that 261 copies of questionnaire were administered on respondents, 250 were returned (response rate of $96 \%$ ), while 11 copies of the questionnaire were not returned (non-response rate of $4 \%)$. Therefore, 250 copies were returned, hence used for the analysis.

Table 2: Responses rate on creative rethinking could engender action-driven plan for dramatic improvement on quality improvement and cutting down operational costs for the desired performance.

\begin{tabular}{|lcc|}
\hline Responses & Frequency & Percentage $(\%)$ \\
\hline Strongly Disagree & 15 & 6 \\
Disagree & 10 & 4 \\
Undecided & 15 & 6 \\
Agree & 102 & 41 \\
Strongly Agree & 108 & 43 \\
Total & 250 & 100 \\
\hline
\end{tabular}

Source: Field Survey, (2016)

Table 2 above shows that $15(6 \%)$ of the total respondents strongly disagree and $10(4 \%)$ of the respondents disagree on the opinion that creative rethinking could engender action-driven plan for dramatic improvement on quality improvement and cutting down operational costs for the desired performance, 102 $(41 \%)$ of the respondents agree and $108(43 \%)$ of the respondents strongly agree while $15(6 \%)$ of the total respondents were undecided.

\subsection{Response Data relating to Radical change and Market share}

Table 3: Responses rate on the extent to which changing the existing structure and design could help the organization to improve their product quality that results to increased market share.

\begin{tabular}{|lcc|}
\hline Responses & Frequency & Percentage $(\%)$ \\
\hline Strongly Disagree & 25 & 10 \\
Disagree & 15 & 6 \\
Undecided & 10 & 4 \\
Agree & 75 & 30 \\
Strongly Agree & 125 & 50 \\
Total & 250 & 100 \\
\hline
\end{tabular}

Source: Field Survey, (2016)

Table 3 above shows that $25(10 \%)$ of the total respondents strongly disagree with the statement, 15 $(6 \%)$ of the respondents disagree, $75(30 \%)$ of the respondents agree and $125(50 \%)$ of the respondents strongly agree to the opinion that changing the existing structure and design could help the organization to improve their product quality that results to increased market share., while $10(4 \%)$ of the total respondents were undecided.

\subsection{Response Data relating to Fundamental thinking and Business Sustainability}

Table 4: Responses rate on whether asking basic questions on mode of operations, value system, vision, mission and customer requirements, would help the operations managers to make pertinent decisions with respect to the demands of the environment.

\begin{tabular}{|lcc|}
\hline Responses & Frequency & Percentage $(\%)$ \\
\hline Strongly Disagree & 14 & 6 \\
Disagree & 26 & 10 \\
Undecided & 20 & 8 \\
Agree & 55 & 22 \\
Strongly Agree & 135 & 54 \\
Total & 250 & 100 \\
\hline
\end{tabular}

Source: Field Survey, (2016) 
Table 4 above shows that $14(6 \%)$ of the total respondents strongly disagree with the statement, 26 $(10 \%)$ of the respondents disagree, $55(22 \%)$ of the respondents agree and $135(54 \%)$ of the respondents strongly agree to the opinion that asking basic questions on mode of operations, value system, vision, mission and customer requirements, would help the operations managers to make pertinent decisions with respect to the demands of the environment, while $20(8 \%)$ of the total respondents were undecided.

Table 5: Responses rate on whether commitment to work, meeting customer's demands, and keeping your promises as part of service improvement could sustain the line of the business.

\begin{tabular}{|lcc|}
\hline Responses & Frequency & Percentage $(\%)$ \\
\hline Strongly Disagree & 10 & 4 \\
Disagree & 24 & 10 \\
Undecided & 16 & 6 \\
Agree & 50 & 20 \\
Strongly Agree & 150 & 60 \\
Total & 250 & 100 \\
\hline
\end{tabular}

Source: Field Survey, (2016)

Table 5 above shows that $10(4 \%)$ of the total respondents strongly disagree with the statement, 24 $(10 \%)$ of the respondents disagree, $50(20 \%)$ of the respondents agree and $150(60 \%)$ of the respondents strongly agree to the opinion that commitment to work, meeting customer's demands, and keeping your promises as part of service improvement could sustain the line of the business, while $20(8 \%)$ of the total respondents were undecided.

\subsection{Generation of Data for Testing Hypotheses}

Data generated from the respondents via questionnaire are presented herein for the testing of the three formulated hypotheses of this study.

4.3.1 Composite data for Testing Hypothesis 1.

$\mathrm{H}_{01}$ : Creative rethinking does not significantly relate to profitability of Innoson Technical and Industrial Company, Emene, Enugu.

$\mathrm{H}_{\mathrm{a} 1}$ : Creative rethinking significantly relates to profitability of Innoson Technical and Industrial Company, Emene, Enugu

Table 6: Summary of Responses to Questionnaire Items relating to Hypothesis One

\begin{tabular}{lccc}
\hline $\begin{array}{l}\text { Questionnaire } \\
\text { Items }\end{array}$ & $\begin{array}{l}\text { No of } \\
\text { observations }\end{array}$ & $\begin{array}{l}\text { Sum of Responses for } \\
\text { creative rethinking (X) }\end{array}$ & $\begin{array}{l}\text { Sum of Responses for } \\
\text { profitability (Y) }\end{array}$ \\
\hline 10 & 250 & 1025 & -- \\
11 & 250 & --- & 1050 \\
\hline
\end{tabular}

Source: Field survey, 2016.

Table 6 shows the summary of responses to questionnaire items 10, creative rethinking (X) and 11, profitability (Y) relating to hypothesis one. Details of the responses to these questionnaire items are presented in Appendix 1. The sum of responses for questions 10 and 11 are $X=1025$ and $Y=1050$, respectively.

\subsubsection{Composite Data for Testing Hypothesis 2.}

$\mathrm{H}_{02}$ : Radical change does not significantly relate to market share of Innoson Technical and Industrial Company, Emene, Enugu.

$\mathrm{H}_{\mathrm{a} 2}$ : Radical change significantly relate to market share of Innoson Technical and Industrial Company, Emene, Enugu.

Table 7: Summary of Responses to Questionnaire Items relating to Hypothesis Two

\begin{tabular}{|c|c|c|c|}
\hline $\begin{array}{l}\text { Questionnaire } \\
\text { Items }\end{array}$ & $\begin{array}{l}\text { No of } \\
\text { observations }\end{array}$ & $\begin{array}{l}\text { Sum of Responses for } \\
\text { Radical change }(\mathrm{X})\end{array}$ & $\begin{array}{l}\text { Sum of Responses for } \\
\text { Market share }(\mathrm{Y})\end{array}$ \\
\hline 16 & 250 & 1042 & -- \\
\hline 17 & 250 & --- & 1055 \\
\hline
\end{tabular}

Source: Field survey, 2016.

Table 7 shows the summary of responses to questionnaire items 16, radical change (X) and 17, Market share (Y) relating to hypothesis Two. Details of the responses to these questionnaire items are presented in Appendix 2. The sum of responses for questions 16 and 17 are $X=1042$ and $Y=1055$, respectively. 


\subsubsection{Composite Data for Testing Hypothesis 3.}

$\mathrm{H}_{03}$ : Fundamental thinking does not significantly relate to business sustainability of Innoson Technical and Industrial Company, Emene, Enugu

$\mathrm{H}_{\mathrm{a} 3}$ : Fundamental thinking significantly relates to business sustainability of InnosonTechnical and Industrial Company, Emene, Enugu.

Table 8: Summary of Responses to Questionnaire Items relating to Hypothesis Three.

\begin{tabular}{|c|c|c|c|}
\hline $\begin{array}{l}\text { Questionnaire } \\
\text { Items }\end{array}$ & $\begin{array}{l}\text { No of } \\
\text { observations }\end{array}$ & $\begin{array}{l}\text { Sum of Responses for } \\
\text { fundamental thinking }(\mathrm{X})\end{array}$ & $\begin{array}{c}\text { Sum of Responses for } \\
\text { Business sustainability (Y) }\end{array}$ \\
\hline 21 & 250 & 1035 & -- \\
\hline 22 & 250 & --- & 1040 \\
\hline
\end{tabular}

Source: Field survey, 2016.

Table 8 shows the summary of responses to questionnaire items 21, Fundamental thinking (X) and 22, Business sustainability (Y) relating to hypothesis Three. Details of the responses to these questionnaire items are presented in Appendix 3. The sum of responses for questions 21 and 22 are $X=1035$ and $Y=1040$, respectively.

\subsection{Testing Hypotheses}

Table 9: Test of Hypothesis 1:

\begin{tabular}{lccccc}
\hline No & X & Y & XY & $X^{2}$ & $Y^{2}$ \\
\hline 250 & 1025 & 1050 & 4425 & 4450 & 4570 \\
\hline
\end{tabular}

Source: Field survey, 2016.

Table 9 shows the summary of independent variable (X) and dependent variable $(\mathrm{Y})$ computations needed to test hypothesis 1 , as shown in Table 6. Details of the data used in these computations are presented in Appendix1 of this dissertation. From Table 9 above, number of respondents $=250, \sum \mathrm{X}=1025, \sum \mathrm{Y}=1050$, $\sum X Y=4425, \sum X^{2}=4450$ and $\sum Y^{2}=4570$.

$$
\begin{aligned}
& \mathrm{n} \sum \mathrm{XY}-\left(\sum \mathrm{X}\right)\left(\sum \mathrm{Y}\right) \\
& r=\sqrt{\left(n \sum X^{2}-(\Sigma X)^{2}\left(n \Sigma Y^{2}-(\Sigma Y)^{2}\right.\right.} \\
& r=\frac{250 \times 4425-1025 \times 1050}{\sqrt{\Gamma(250 \times 4450-10.50625) 1 \Gamma(250 \times 4570-1102500}} \\
& \text { [ } \\
& r=\frac{1106250-1076250}{\sqrt{61875 \times 40000}} \\
& \begin{array}{l}
r=\frac{30000}{\sqrt{2475000000}} \\
r=\frac{30000}{49749} \\
r=0.60
\end{array} \\
& \text { Coefficient of determination } \begin{aligned}
\left(\mathrm{r}^{2}\right) & =(0.60)^{2} \\
\mathrm{r}^{2} & =0.36
\end{aligned}
\end{aligned}
$$

Computation of t value:

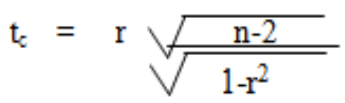


Substituting $\mathrm{r}, \mathrm{r}^{2}$ and $\mathrm{N}$ with $0.60,0.36$ and 250 values, we have:

$$
\begin{aligned}
t_{c} & =0.60 \sqrt{1250.26} \\
t_{c} & =\frac{0.60 \sqrt{248}}{\sqrt{0.64}} \\
t_{c}= & \frac{0.60(15.75)}{0.8} \\
t_{c}= & 11.81
\end{aligned}
$$

For hypothesis $1: \mathrm{r}=0.60, \mathrm{r}^{2}=0.36$ and $\mathrm{t}_{\mathrm{c}}=11.83$.

Table 10: Test of Hypothesis 2

\begin{tabular}{lccccc}
\hline No & $\mathrm{X}$ & $\mathrm{Y}$ & $\mathrm{XY}$ & $\mathrm{X}^{2}$ & $\mathrm{Y}^{2}$ \\
\hline 250 & 1042 & 1055 & 4627 & 4620 & 4650 \\
\hline
\end{tabular}

Source: Field survey, 2016.

Table 10 presents the summary of independent variable $(\mathrm{X})$ and dependent variable $(\mathrm{Y})$ computations needed to test hypothesis 2, as shown in Table 7. Details of the data used in these computations are presented in Appendix 2 of this dissertation. From Table 10 above, number of respondents $=250, \Sigma X=1042, \sum \mathrm{Y}=1055$, $\sum X Y=4627, \sum X^{2}=4620$ and $\sum Y^{2}=4650$.

$$
\begin{aligned}
& \mathrm{n} \sum \mathrm{XY}-\left(\sum \mathrm{X}\right)\left(\sum \mathrm{Y}\right) \\
& r=\sqrt{\left(n \Sigma X^{2}-(\Sigma X)^{2}\left(n \Sigma Y^{2}-(\Sigma Y)^{2}\right.\right.} \\
& r=\frac{250 \times 4627-1042 \times 1055}{\sqrt{[(250 \times 4620-10,85764)][(250 \times 4650-1055 \times 1055)]}} \\
& r=\quad \sqrt{69236 \times 49494} \\
& \mathrm{r}=\quad \frac{62067}{\sqrt{3425451100}} \\
& r=\frac{62067}{68527} \\
& \mathrm{r}=\quad 0.91 \\
& \text { Coefficient of determination }\left(\mathrm{r}^{2}\right) \quad \begin{aligned}
= & (0.91)^{2} \\
\mathrm{r}^{2} & =0.8281
\end{aligned}
\end{aligned}
$$

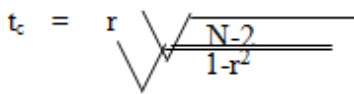

Substituting $\mathrm{r}$ and $\mathrm{N}$ with 0.91 and 250 values, we have:

$$
\mathrm{t}_{n}=\sqrt[0.91]{\sqrt{250-2}}
$$

$$
\begin{aligned}
& \mathrm{t}_{\mathrm{c}}=\frac{0.91 \sqrt{248}}{\mathrm{t}_{\mathrm{c}}}=\frac{0.91(15.75)}{0.1719} \\
& \mathrm{t}_{\mathrm{c}}=34.620 .414
\end{aligned}
$$

For hypothesis $2: \mathrm{r}=0.91, \mathrm{r}^{2}=0.8281$ and $\mathrm{t}_{\mathrm{c}}=34.62$ 
Table 11: Test of Hypothesis 3

\begin{tabular}{cccccc}
\hline No & X & Y & XY & $X^{2}$ & $Y^{2}$ \\
\hline 250 & 1035 & 1040 & 4530 & 4650 & 4685 \\
\hline
\end{tabular}

Source: Field survey, 2016.

Table 11 above shows the summary of independent variable (X) and dependent variable (Y) computations needed to test hypothesis 3, as shown in Table 8. Details of the data used in these computations are presented in Appendix 3 of this work. From Table 11 above, number of respondents $=250, \sum \mathrm{X}=1035, \sum \mathrm{Y}$ $=1040, \sum X Y=4530, \sum X^{2}=4650$ and $\sum Y^{2}=4685$.

$$
\begin{aligned}
& \mathrm{n} \Sigma \mathrm{XY}-(\Sigma \mathrm{X})(\Sigma \mathrm{Y}) \\
& r=\sqrt{\left(n \sum X^{2}-\left(\sum X\right)^{2}\left(n \sum Y^{2}-\left(\sum Y\right)^{2}\right.\right.} \\
& r=250 \times 4530-1035 \times 1040 \\
& \sqrt{[(250 \times 46250-10,11225)][(251 \times 4685-1081600)]} \\
& r=\sqrt{73856 \times 54125} \\
& r=\frac{58560}{\sqrt{9049084875}} \\
& r=\frac{58560}{95126} \\
& r=\quad 0.62 \\
& \mathrm{r}^{2}=0.3844
\end{aligned}
$$

Computation of $t_{c}$ value:

$$
\mathrm{t}_{\mathrm{c}}=\frac{\mathrm{r}}{\sqrt{\mathrm{n}-2}}
$$

Substituting $\mathrm{r}$ and $\mathrm{N}$ with 0.62 and 250 values, we have:

$$
\begin{aligned}
\mathrm{t}_{\mathrm{r}}= & \frac{0.62 \sqrt{248}}{\sqrt{1-0.3844}} \\
\mathrm{t}_{\mathrm{c}}= & 0.62 \sqrt{248} \\
\mathrm{t}_{\mathrm{c}}= & \frac{0.62(15.75)}{0.6156} \\
\mathrm{t}_{\mathrm{c}}= & 0.7846 \\
& 12.46
\end{aligned}
$$

For hypothesis $3: \mathrm{r}=0.62, \mathrm{r}^{2}=0.3844$ and $\mathrm{t}_{\mathrm{c}}=12.45$

\subsubsection{Creative Rethinking and Profitability}

\section{Findings}

In order to establish the desired measure for creative rethinking and organizational profitability, questions 10 and 11 were loaded as a strong construct that measure Creative rethinking and profitability (see appendix iv). This was shown by a high Bartlett Test of Sphericity of $\left(\chi^{2} 352.075, \mathrm{p}<0.050\right)$ and the KaiserMeyer-Olkin measure of sampling adequacy was also greater than 0.5 (KMO - 0.675), which shown that the loaded instruments for the stated hypothesis were appropriate (see appendix vi, pg. 106). Conversely, there was a high communalities across the corresponding component scale. The result of hypothesis one shows a 
significant relationship between creative rethinking and organizational profitability of Innoson Technical Industrial Company in the selected plastic manufacturing firms in South East, Nigeria. The result of the correlation coefficient ( $\mathrm{r}$ ) is 0.60 . This, however, indicates that there is a significant positive relationship between creative rethinking and organizational profitability. More so, the coefficient of determination $\left(\mathrm{r}^{2}\right)$ is 0.36 . This implies that $36 \%$ total variation in organizational profitability is accounted for, by the creative rethinking Innoson Company engages that lead to new ideas through effective implementation of business process reengineering. Therefore, business process reengineering has a considerable influence on organizational profitability. The test of the significance of correlation coefficient $\left(t_{c}\right)$ shows that the calculated critical value of $t_{c}$ is 11.83 which is greater than the critical (table) value, at 5\% error margin. However, these results show that the first objective of the study namely: to what extent does creative rethinking relate to profitability of Innoson Technical and Industrial Company, Emene, Enugu, was achieved. The significant effect of creative rethinking on organizational profitability found in this study is consistent with the findings of McGrill (2012). McGrill (2012) found that creative idea has linear relationship with organizational profitability.

\subsubsection{Radical Change and Market share}

In testing hypothesis two, questionnaire items 16-17 were collated and loaded as a measuring construct of radical change and market share of Innoson Technical and Industrial Company. The component factor analysis via varimax rotation shown a Bartlett Test of Sphericity of $\left(\chi^{2} 239.681, p<0.050\right)$. This, however, shows that the construct components of questionnaire items 16-17 were appropriate. More so, Kaiser-MeyerOlkin measure of sampling adequacy was also greater than 0.5 (KMO, 0.643) (see appendix vi, pg. 108) The result of hypothesis two presents that there is a significant positive relationship between radical change and market share of Innoson Technical and Industrial Company. The result of the correlation coefficient (r) is 0.91 . This however shows that there is a significant positive relationship between radical change and market of Innoson Company. More so, the coefficient of determination $\left(\mathrm{r}^{2}\right)$ is 0.8281 . This implies that $83 \%$ total variation in organizational market share is accounted for, by the level of radical change the organization put in place especially on their products. Therefore, radical change has a significant effect on customer loyalty to organizational products. Beside, the result of the coefficient of determination $\left(\mathrm{r}^{2}\right)$, the test of the significance of correlation coefficient $\left(\mathrm{t}_{\mathrm{c}}\right)$ shows that the calculated critical value of $\mathrm{t}_{\mathrm{c}}$ is 34.62 which is greater than the critical (table) value, at $5 \%$ level of significance.

These results however show that the second objective of the study namely: to what extent does radical change relates to market share of Innoson Technical and Industrial Company, Emene, Enugu, was achieved. Therefore, the significant effect of radical change on market share found in this study is consistent with the findings of Tan, (2006). Who examined the impact of securing customer loyalty through business process reengineering.

\subsubsection{Fundamental Thinking and Business sustainability}

In an attempt to establish the measuring construct of service improvement and business sustainability, questionnaire items 21- 22 were collated and loaded to measure fundamental thinking and business sustainability. The Bartlett Test of Sphericity was significant $\left(\chi^{2} 339.681, p<0.050\right)$. Kaiser-Meyer-Olkin measure of sampling adequacy was also greater than 0.5 (KMO, 0.619) (see appendix vi, pg. 110). This affirms that the measuring scale was appropriate for fundamental thinking and business sustainability of Innoson Technical and Industrial Company. The result of hypothesis three shows that there is a significant positive relationship between fundamental thinking and business sustainability of Innoson Technical and Industrial Company, Emene. The result of the correlation coefficient (r) is 0.62. This, however, shows that there is a significant positive relationship between fundamental thinking and business sustainability. More so, the coefficient of determination $\left(\mathrm{r}^{2}\right)$ is 0.3844 . This implies that $38 \%$ total variation in business sustainability is accounted for, by the level of fundamental thinking the ope. Therefore, service improvement has a significant effect on business sustainability of Inrations managers engages in an attempt to produce new idea. Aside, the result of the coefficient of determination $\left(\mathrm{r}^{2}\right)$, the test of the significance of correlation coefficient $\left(\mathrm{t}_{\mathrm{c}}\right)$ shows that the calculated critical value of $t_{c}$ is 12.45 which is greater than the critical (table) value, at $5 \%$ level of significance.

These results however show that the third objective of the study namely: to what extent does fundamental thinking relates to business sustainability of Innoson Technical and Industrial Company, Emene, Enugu, was achieved. The effect of fundamental thinking on business sustainability found in this study is consistent with the findings of Ndife (2010). Therefore, Nidfe (2010) found a significant relationship between business process reengineering and business performance $(r=0.54)$ of selected manufacturing firms in Lagos State. 


\section{Conclusion}

From the findings, the study concludes that there is a significant relationship between business process reengineering and organizational performance. The implication of the aforementioned is that effective business process reengineering will perhaps result to improved performance. The study provided evidence that creative rethinking, radica change and fundamental thinking as decomposed variables predict organizational performance. The imperativeness of the foregoing suggests that organizations that wish to thrive in the changing business environment should pay adequate attention to issues relating to business process reengineering. Therefore, the significant relationship between business process reengineering and performance derive from having proper understanding of the prevailing elements of the environment. This understanding perhaps would enable organization re-design their business process in line with the changing business environment.

Another implication is that with clear understanding of the business environment, an organization is better guided on the specific areas to redesign for radical improvement. The result shows a significant relationship between creative rethinking significantly relate to profitability. This implies that redesigning the business process through pricing strategy, attract more customer patronage on company's products and the resultant effects is profit maximization. In the same vein, there exists a significant relationship between radical change and business sustainability. It means that when firm redesign their core business processes in responding to the changes to the environment makes the firm proactive which would result to business sustainability and vice verse.

\section{Recommendations}

From the findings of this study, conclusion arrived at; the following are recommendations arising therefrom: The management of Innoson Technical and Industrial Company should pay adequate attention to issues relating to business process reengineering, taking into cognizance its pertinent role in radical improvement on creative rethinking, radical change and fundamental thinking that predict organizational performance. Operations managers should take effective measures in assessing the prevailing environment parameters in order to re-design their business processes effectively. Innoson Technical and Industrial Company should employ trained personnel with cognate experience on business process reengineering. This will ensure efficiency and effectiveness in implementing business process reengineering for the desired performance. Effective implementation of business process reengineering thrive organizations in the changing business environment.

The management of Innoson Technical and Industrial Company should take effective measures in institutionalizing business process re-engineering giving the nature of business environment, to address the problems of loss of customer patronage, attrition and defection on their products.

The management of Innoson Technical and Industrial Company should involve employees' in business process reengineering exercise to achieve total wisdom management. The involvement of employees' is essentially imperative because it would arm them with the desired dexterity necessary for effective implementation of business process reengineering.

\section{References}

[1]. Adeyemi, S.M. (2000), Marketing Management Strategies. Ogun: Olufemi Publications.

[2]. Arora, K.C. (2010), Total Quality Management. New Delhi: S.K Kataria \& Sons.

[3]. Beck, K. (2014), Innovation Models and Business Process Re-design. Canadian Journal of Business Studies, Vol.3, (4),Pp.102-110.

[4]. Bruce, D.I. (2010), Process Innovation. Reengineering works through Information Technology. London: Harvest Business School Press.

[5]. Champy, M. (1993), Strategies for Effective Business Process Reengineering in Organizations. Boston: McMilliam Press

[6]. Chukwu, U.C. (2004), Accounting Principles and practice. Abakaliki: New Concept Publishing.

[7]. David, F.H. (2003), Impact Assessment of Business Process Reengineering on Performance. Journal of Management Information System, Vol.6, (4), Pp. 225-230.

[8]. Docky, S.D. (2000), Performance Measures through Business Re-design. New Delhi: Eaglewood Press.

[9]. Freeman, G.H. (2014), Business Process Re-engineering. Boston: Harvest Business School Press.

[10]. Goldhuhl, G.(1996), Generic Framework of Business Actions. New Delhi: Thurgh Press.

[11]. Goetsch, B. and Davis, K.L. (2000), Business Process Reengineer. A Book of Reading. New York: Eaglewood Press.

[12]. Guru, V.K.(2013), Business Process Re-engineering Improvement. London: McGraw-Hill.

[13]. Hammer, L.R. (2014), Procedures for Effective Application of Business Process Reengineering in Organizations. International Journal Interdisciplinary Studies, Vol.4, (5),Pp. 456-460.

[14]. Hickson, R.E. (2009), Business Process Reengineering: A Book of Discourse. New Delhi: Eagle-Hill.

[15]. Huge, M.V. (2000), Effects of Business Process Reengineering on Organizational Effectiveness.Journal of Management Information System, Vol.6, (4), Pp. 240-246.

[16]. Innoson Technical and Industrial Company Bulletin (2015), Performance Tips in Meeting the Demands of Business Environment. Enugu: Innoson Publications.

[17]. Jain, K.C., and Aggarwal, L.N. (2011), Production Planning Control and Industrial Management. New Delhi: Khanna Publishers.

[18]. John, V.O. (2000), Effects of Business Process Re-design on Organizational Performance of Plastic Manufacturing Firms, South-East, Nigeria. The Nigerian Journal of Management Research, Vol.3, (1), Pp.145-150.

[19]. Klein, G.J. (2000), Effects of Business Process Reengineering in Meeting the Demands of the Changing Business Environment. Journal of Community Psychology, Vol.38, No.2, pp.25-31.

[20]. Klotter, F.K. (2012), Business Process Reengineer. A key for Sustained Competitiveness. Boston: Lyce Publication.

[21]. Martins, B.H. (2012), Application of Business Process Reengineering on Business Performance. Journal of Social Sciences, Vol.9, (6), 254-260. 


\section{Business Process Reengineering And Organizational Performance: A Study Of Innoson Technical}

[22]. Miller, N.O. (2000), Imperativeness of Business Process Reengineering in the Business World.Algah: Ahmed Publications.

[23]. Moruah, G.H. (2012), Enhancing Organizational Performance through Service Quality.Journal of Educational Research, Vol. 1. No.205, pp. 27-35.

[24]. McGrill, N.I. (2012), Effects of Reducing Cost Strategy on Profitability. Journal of Innovation and Development, Vol. 4, No. 9, pp. 121128.

[25]. Ndife, G.J. (2010), Effects of Business Process Reengineering on Business Stability, Journal of Innovation and Development, Vol.6, No. 8, pp. 105-116.

[26]. Nick, J.L., and Flick, K.M. (2000), Financial Management. $2^{\text {nd }}$ Edition, London: Eagle-Hill Pree.

[27]. Noah, D.H. (2001), Business Process Reengineering a leeway for Business Sustainability. Journal of Business logistics, Vol.8, (9), Pp.234-240.

[28]. Sengupta, N., Bhattacharya, M.S. and Sengupta, N.R. (2012), Managing Change in Organizations. New Delhi: PHI Learning Private Limited.

[29]. Stephen, A.J. (2015), Breakpoint Strategies for Market Dominance. New York: John Wiley and Sons.

[30]. Tan, F. H. (2006), Securing Customer Loyalty through Business Process Reengineering. Journal of Social Sciences, Vol. 4, No. 6. Pp. 421-435.

[31]. Tosin, A.O. (2000), Business Process Re-engineering for Total Quality Management (TQM). Quality Management Journal Vol.3 (3),Pp. 20-38.

[32]. Veer, T.D. (2000), Performance Management. $3^{\text {rd }}$ Edition, New Delhi: Eagle-Hill Press.

[33]. Willy, F.G. (2014), Achieving Radical Improvement on Business Performance. New York: John Willy and Sons. 